\title{
Rhabdomyolysis Secondary to Quetiapine and Olanzapine Intoxication
}

\author{
Olanzapin ve Ketiapin intoksikasyonuna Ikincil Rabdomiyoliz
}

Emine Akıncı', Ramazan Köylü², Nazire Belgin Akıllı², Başar Cander²

'Department of Emergency Medicine, Keçiören Training and Research Hospital, Ankara, Turkey

2Department of Emergency Medicine, Konya Training and Research Hospital, Konya, Turkey

\section{ABSTRACT}

Introduction: Rhabdomyolysis is a rare and potentially serious adverse drug reaction to antipsychotic medicines. We present a case that developed rhabdomyolysis following the intake of 200 mg olanzapine and $6 \mathrm{gr}$ quetiapine for a suicide attempt.

Case Report: A 49-year-old male patient was submitted to the emergency department with complaint of taking an excessive amount of olanzapine (10 mg) and quetiapine $(300 \mathrm{mg})$ in order to commit suicide. As to the laboratory analysis, Creatine Kinase (CK): 7761 U/L, Creatine Kinase Myocardial Band (CKMB): $178 \mathrm{U} / \mathrm{L}$, $\mathrm{pH} 7.44, \mathrm{HCO}_{3}$ : $22.9 \mathrm{mmol} / \mathrm{L}$, lactate: $0.50 \mathrm{mmol} / \mathrm{L}$, and the urine myoglobin test was positive. The other parameters were within the normal limits. The patient had been using the medicines for 2 years and has not been come across that high level for enzymes which had not previously been detected. On the second day, the results were CK: $4008 \mathrm{U} / \mathrm{L}$ and CKMB: $100 \mathrm{U} / \mathrm{L}$; on the third day, CK: $1924 \mathrm{U} / \mathrm{L}$ and CKMB: $86 \mathrm{U} / \mathrm{L}$; and on the fourth day, CK: 1510 $\mathrm{U} / \mathrm{L}$ and CKMB: $80 \mathrm{U} / \mathrm{L}$. During hospitalization, no renal function disorder or metabolic acidosis occurred. On the fifth day, the patient was discharged.

Conclusion: After taking an excessive amount of atypical antipsychotic drugs, patients should necessarily be followed for the risk of developing of rhabdomyolysis.

Keywords: Rhabdomyolysis, olanzapine, quetiapine

Received: 12.05.2013 Accepted: 25.07.2013

\section{ÖZET}

Giriş: Rabdomiyoliz, antipsikotik ilaçlara bağlı nadir gelişen ve potansiyel olarak ciddi bir ilaç reaksiyonudur. Biz intihar amaçlı 200 mg Olanzapinve 6 gr Ketiapin alımı sonrasında rabdomiyoliz gelişen olgumuzu sunuyoruz.

Olgu Sunumu: Kırk dokuz yaşında erkek hasta acil servise intihar amaçlı fazla miktarda Olanzapin ve Ketiapin içmesi nedeniyle getirildi. Laboratuar tetkiklerinde Kreatin kinaz (CK): 7761 U/L, Kreatin kinaz myokardial band (CKMB): $178 \mathrm{U} / \mathrm{L}, \mathrm{pH}:$ 7,44, , Laktat: 0,50 $\mathrm{mmol} / \mathrm{L}$ olup idrarda myoglobin testi pozitifti. Diğer parametreler normal sınırlar içerisindeydi. Bu ilaçları 2 yıldır kullanan hastanın daha önce bakılan laboratuar tahlillerinde enzim yüksekliklerine rastlanmamıştı. 2. Gün CK: 4008 U/L, CKMB: 100 U/L, 3. Gün CK: 1924 U/L, CKMB: 86 U/L, 4. Gün CK: 1510 U/L, CKMB: 80 U/L geldi. Yattığı süre içerisinde hastada böbrek fonksiyon bozukluğu ve metabolik asidoz gelişmedi. Yatışının 5. gününde taburcu edildi.

Sonuç: Aşırı doz atipik antipsikotik drug alımlarından sonra mutlaka hastalar rabdomyoliz açısından da takip edilmelidir.

Anahtar Kelimeler: Rabdomiyoliz, olanzaopin, ketiapin

Geliş Tarihi: 12.05.2013 Kabul Tarihi: 25.07.2013

\section{Introduction}

Drugs, like quetiapine and olanzapine, are commonly used to treat behavioral disorders. The side effects of quetiapine are dizziness, somnolence, headache, dyslipidemia, gastrointestinal, and metabolic changes and less frequently leukopenia, increases in transaminases, blurred vision, and others (1). Rhabdomyolysis is a rare and potentially serious adverse drug reaction to antipsychotic medicines (2). Cases of rhabdomyolysis have been reported separately caused by olanzapine and quetiapine (2, 3). Most of the reported cases of rhabdomyolysis are chronic drug-induced rhabdomyolysis. Herein, we report a case that developed rhabdomyolysis following the intake of 200 mg olanzapine and 6 gr quetiapine. 


\section{Case Report}

A 49-year-old male patient was brought to the emergency department (ED) by family members after ingesting $200 \mathrm{mg}$ of olanzapine $(10 \mathrm{mg})$ and 6 gram of quetiapine $(300 \mathrm{mg})$ for a suicide attempt. The patient ingested medications approximately 1 hour prior to arrival at the ED and had not subsequently vomited. He was diagnosed as bipolar disorder before, with the finding that the drugs in question were also prescribed to him. The patient was confused, with a Glasgow Coma Scale (GCS) of 14 (E: 3, M: 6, V: 5) on physical examination. Body temperature was $36^{\circ} \mathrm{C}$, pulse $70 / \mathrm{min}$, breath per minute $12 / \mathrm{min}$, and blood pressure 120/80 $\mathrm{mm} \mathrm{Hg}$. There was no abnormality noted in another systemic examination. As to the laboratory analysis, the results were as follows: haemoglobin ( $\mathrm{Hgb}): 13,5 \mathrm{gr} / \mathrm{dl}$, Aspartate amino transferase (AST):157 U/L, Alanine aminotransferas (ALT):56 U/L, Creatine Kinase (CK):7761 U/L, Creatine Kinase Myocardial Band (CKMB): $178 \mathrm{U} / \mathrm{L}$, troponin: 0.03ng/ml, $\mathrm{pH} 7.44, \mathrm{pCO}_{2}$ : $34.8 \mathrm{~mm} \mathrm{Hg}, \mathrm{pO}_{2}: 31.1 \mathrm{~mm} \mathrm{Hg}, \mathrm{HCO}_{3}: 22.9 \mathrm{mmol} / \mathrm{L}$, and lactate: 0.50 $\mathrm{mmol} / \mathrm{L}$; the urine myoglobin test was positive, and blood ethanol level was negative. The other parameters were within the normal limits. Gastric lavage was performed with 3 liters of normal saline (NS). Activated charcoal was administered at $1 \mathrm{gr} / \mathrm{kg}$, and $250 \mathrm{ml} /$ hour of NS infusion was started before the patient was admitted to the intensive care unit (ICU). Also, 20\% mannitol 4x50 g, furosemide $3 \times 20 \mathrm{mg}$, and sodium bicarbonate $\left(\mathrm{NaHCO}_{3} 40\right.$ meq were added to the therapy. The patient had been using the medicines (olanzapine $10 \mathrm{mg} /$ day, quetiapine $300 \mathrm{mg} /$ day) for 2 years. Elevation of enzymes had not previously been detected by laboratory analysis. During hospitalization, no renal function disorder or metabolic acidosis occurred. Levels for urea and creatine were in physiological limits. The patient's enzyme values are shown in Table 1. Therapy with diuretics and $\mathrm{NaHCO}_{3}$ was eventually stopped. On the fifth day of hospitalization, the patient was discharged with recommendations after consultation with psychiatrists.

\section{Discussion}

Rhabdomyolysis is a sort of damage to skeletal muscles caused by traumatic or non-traumatic reasons and participation of cell contents to the circulation. The most common causes of rhabdomyolysis are alcohol abuse, muscle exertion, muscle compression, and the use of certain medications or illicit drugs. On the other hand, causes may also be of traumatic, heat-related, ischemic, infectious, inflammatory, metabolic, and endocrinological origin (4). Rhabdomyolysis is a rare and potentially serious adverse drug reaction to antipsychotic medicines. Serum creatine kinase (CK) elevation in acute psychotic disorders was defined for the first time in 1960 (5). CK levels in patients with psychotic disorders may be due to various causes. It may be due to increased physical activity during psychotic episodes or can also occur due to neuromuscular dysfunction (2). Less commonly, it may be due to long-term use of anti-psychotic drugs, seizures, neuroleptic malignant syndrome, or trauma (5). The most common psychiatric drugs that cause rhabdomyolysis are clozapine, loxapine, melperone, risperidone, olanzapine and haloperidol (6). Meltzer has investigated the elevation of serum CK in patients receiving antipsychotic medication. Reported serum CK levels were identified
Table 1. Enzymes and creatinine levels of patient*

\begin{tabular}{lccc} 
& $\begin{array}{c}\text { CK } \\
(\mathrm{U} / \mathrm{l})\end{array}$ & $\begin{array}{c}\text { CKMB } \\
(\mathrm{U} / \mathrm{l})\end{array}$ & $\begin{array}{c}\text { Creatinine } \\
(\mathrm{mg} / \mathrm{dl})\end{array}$ \\
\hline $1^{\text {st }}$ day & 7761 & 178 & 1,3 \\
$2^{\text {nd }}$ day & 4008 & 100 & 1,3 \\
$3^{\text {rd }}$ day & 1924 & 86 & 1,0 \\
$4^{\text {th }}$ day & 1510 & 80 & 0,9 \\
$5^{\text {th }}$ day & 760 & 56 & 1 \\
*Figures represent daily measurements. $^{\text {CK: Creatine kinase; CKMB: Creatine Kinase Myocardial Band }}$ & \\
\hline
\end{tabular}

between 5 days and 2 years. At the time of diagnosis, they did not detect any signs of trauma or hyperactivity. Most cases of rhabdomyolysis reported in the literature are due to chronic use of drugs. In our patient, we supposed that development of rhabdomyolysis in the early period was due to taking large amounts of medicines. The patient was using this medication regularly for 2 years, and there was no enzyme elevation in the patient's records.

Anti-psychotic drugs disclosure serotonin by antagonizing 5HT receptors. In animal experiments, it has been shown that serotonin was conducted into muscles by passive diffusion and caused muscle necrosis and CK elevation in mice (7). In our case, early developed rhabdomyolysis may have also occurred by a similar mechanism. We also excluded the presence of neuroleptic malignant syndrome (absence of neurological signs and symptoms, hyperthermia, and autonomic dysfunction) and trauma.

In a case reported by Plesnicar et al. (8), approximately 31 hours after ingestion of high doses of quetiapine, rhabdomyolysis patients were admitted to the emergency room. They denoted that the patients were sleeping in this period, and they attributed the rhabdomyolysis to the patients' long-term immobilization (8).

Rhabdomyolysis induced by olanzapine is less frequently observed. In the series reported by Ribeyro et al. (9), CK elevation with varying degrees was found in 21 cases that might have been caused by chronic usage. These enzymes have been noted to return to normal after discontinuation of olanzapine in $85 \%$ of the cases.

The treatment of drug-induced CK elevation and rhabdomyolysis also varies according to the patient's condition. It may be sufficient to stop these drugs in asymptomatic patients who have mild and moderate enzyme elevations without metabolic disorders. But, if there is severe enzyme elevation and metabolic disorders, hospitalization and dialysis may be needed.

\section{Conclusion}

In the case of taking excessive amounts of atypical antipsychotic drugs, patients should be followed for the risk of rhabdomyolysis.

Informed consent: Written informed consent was obtained from patients who participated in this case. 
Peer review: Externally peer-reviewed.

Author contributions: Concept - E.A, N.B.A. Design - E.A.; Supervision - B.C.; Materials - N.B.A.; Data Collection and/or Processing - E.A, N.B.A, R.K.; X.X.; Analysis and/or Interpretation - E.A, N.B.A.; Literature Review - E.A, N.B.A.; Writer - E.A., R.K .; Critical Review - B.C

Conflict of interest: No conflict of interest was declared by the authors.

Financial Disclosure: The authors declared that this study has received no financial support

Hasta Onamı:Yazılı hasta onamı bu olguya katılan hastalardan alınmıştır.

Hakem değerlendirmesi: Dış bağımsız.

Yazar Katkıları: Fikir - E.A, N.B.A. ; Tasarım - E.A. Denetleme B.C.Malzemeler - N.B.A.; Veri toplanması ve/veya işlemesi - E.A, N.B.A, R.K...; Analiz ve/veya yorum - E.A, N.B.A.; Literatür taraması - E.A, N.B.A.; Yazıyı yazan -E.A., R.K.; Eleştirel İnceleme - B.C

Çıkar Çatışması: Yazarlar çıkar çatışması bildirmemişlerdir.
Finansal Destek: Yazarlar bu çalışma için finansal destek almadıkları$\mathrm{nı}$ beyan etmişlerdir.

\section{References}

1. Fernandes PP, Marcil WA. Death associated with quetiapine overdose. Am J Psychiatry 2002; 159: 2114. [CrossRef]

2. Liolios A, Sentissi O. Rhabdomyolysis following Acute Extended-Release Quetiapine Poisoning: A Case Report. Case Rep Psychiatry 2012; 2012 347421.

3. Ribeyron S, Guy C, Koenig M, Cathébras P. Olanzapine induced rhabdomyolysis and serum creatine kinase increase. Rev Med Interne 2009; 30: 477-85. [CrossRef]

4. Saatcioğlu Ö, Yıldız BS, Gökçe E, Tomruk NB. Rabdomiyoliz, alkole bağlı rabdomiyoliz ve akut böbrek yetmezliği. Anatol J Clin Investig 2010: 4: 70-9

5. Bengzon A, Hippius H, Kanig K. Some changes in the serum during treatment with psychotropic drugs. J Nerv Ment Dis 1966; 143: 369-76. [CrossRef]

6. Meltzer HY, Cola PA, Parsa M. Marked elevations of serum creatine kinase activity associated with antipsychotic drug treatment. Neuropsychopharmacology 1996; 15: 395-405. [CrossRef]

7. Stahl SM, Meltzer HY. Serotonin accumulation by skeletal muscle. Exp Neurol 1977; 54: 42-53. [CrossRef]

8. Plesnicar BK, Lasic JK, Plesnicar A. Quetiapine and elevated creatine phosphokinase (CK). Pharmacopsychiatry 2007; 40: 203-4. [CrossRef]

9. Ribeyron S, Guy C, Koenig M, Cathébras P. Olanzapine induced rhabdomyolysis and serum creatine kinase increase]. Rev Med Interne 2009; 30: 477-85. [CrossRef] 